\title{
Application of Blended Learning in Undergraduate Biochemistry Teaching
}

\author{
Xiaoming HANG, Jianchao LI, Yixiao LI, Nian LIU, Yeqing SUN* \\ College of Environmental Science and Engineering, Dalian Maritime University, Dalian City, Liaoning \\ Province, China
}

\begin{abstract}
Biochemistry course, a professional basic course for biological and medical students, is a challenging course for both leaching and learning. The conventional classroom teaching cannot absolutely satisfy the demands of learning. New teaching methods must be explored to improve the quality and efficiency of both teaching and learning. E-learning is a well-accepted tool in supplementary to conventional classroom teaching. In this paper, advantages and limitations of both conventional teaching and e-learning models are presented. A brand-new blended learning model, combined e-learning with conventional lecturebased learning, was applied in biochemistry teaching for undergraduate students of marine biology resources and environments major, in Dalian maritime university, China. Our experience with the use of an e-learning platform is also described.
\end{abstract}

KEYWORD: Biochemistry teaching; blended learning; e-learning; teaching effectiveness

\section{INTRODUCTION}

Biochemistry course is an important fundamental and prerequisite course for both biological and medical undergraduates. The content of biochemistry is vast, the time available for teaching is limited and the number of students in one class is usually large in China. Conventional classroom teaching is the major way in teaching biochemistry course in China, because it can deliver considerable amounts of information to a diverse and large group of students. But the passive participation of students in learning process is an obvious weakness of lecture-based teaching. Moreover, classroom teaching cannot meet the diverse learning demands of individual students in one class.

E-learning, a self-paced learning model involved the use of electronic tools and internet, has been widely used to facilitate self-directed learning with many advantages. Blended teaching model, combined e-learning with face-to-face teaching, is proved to be a powerful way to improve the quality and efficiency of both teaching and learning.

In this paper, several related aspects, including the advantages and limitations of both conventional lecture-based teaching and e-learning models, and how to construct a blended teaching model to improve the teaching effectiveness of biochemistry course, are discussed.

\section{BIOCHEMISTRY COURSE}

\subsection{Biochemistry course for undergraduates}

Biochemistry course is one of the most important fundamental courses in biological and medical sciences. The main focus of biochemistry is the molecules of life (carbohydrates, lipids, proteins and nucleic acids, etc), structure and features of these molecules, as well as their metabolic and chemical reactions during the whole life (development, reproduction, metabolism and activities). As a core discipline, biochemistry has been one of the most advanced fields in biological sciences in recent years, and a great deal of progress has been contributed to genetics, molecule biological and medical science etc. Therefore, biochemistry is a basic and prerequisite course for all undergraduates of biological and medical sciences, and the study of it will provide fundamental background and language for other forthcoming courses, such as cell biology, molecular biology, genomics and proteomics, etc.

The content of biochemistry is vast, full of complex and abstract structures of chemical molecules, as well as intricate biological processes and mechanisms. But the time available for teaching is very limited and the number of students in a class is usually large in China. 


\subsection{Conventional teaching of biochemistry course}

Conventional lecture-based teaching is the major way of teaching undergraduate biochemistry course in China. There are several reasons for this. First, classroom teaching, as the most basic teaching activities, can make the students acquire knowledge quickly and systematically under the guidance of teachers. Second, students in one class can learn together, help and influence each other, which will help the students to cultivate the spirit of cooperation and competition. Last, emotional communications between teachers and students in conventional classroom teaching play an important role in the learning process.

But the limitations of traditional lecture-based teaching mode are obvious. First, when the teacher plays a leading role in the classroom activities, the motivation and participation of students will be suppressed. Second, since the available time for classroom teaching is very limited, the teacher has to deliver considerable amounts of information at a particular pace suitable for the average students, which means not all students are able to assimilate the content of a lecture to the same extent. Academically weak students may find it difficult to keep pace with the lecture progresses, whereas academically excellent students may find it unchallenging and lost of interests. Moreover, the quality and efficiency of lecture-based teaching primarily depends on the responsibility, experience and skill of the teacher, which may be quite variable.

To sum up, a single classroom teaching cannot meet the learning demands of diverse students in one class. It is necessary for teachers to explore new ways to overcome the inherent disadvantages of traditional lecture-based teaching.

\section{E-LEARNING}

\subsection{Definition of E-learning}

E-learning, an abbreviation of electronic-learning, is a new means of learning. It refers to the delivery of a learning, training or education by electronic means. E-learning involves the use of modern tools, such as computers, digital technology, electronic media, teaching and learning software or courseware, and internet (Nichols, 2003).

There are many other definitions of e-learning. Luskin (2010) advocated that the "e" of e-learning should be interpreted to mean "exciting, energetic, enthusiastic, emotional, extended, excellent, and educational" in addition to "electronic". Parks, CEO of ASK International, suggested that the "e" should refer to "everything, everyone, engaging and easy". From these points of views, e-learning is not only a learning environment or resource provided by the modern information technology, but also a new means of learning theory and education technology.

\subsection{Advantages and limitations of e-learning}

There are many advantages of e-learning. It is more flexible than lecture-based teaching. Students can learn whenever or wherever they wish to learn, with a computer or internet. The learning content keeps on updating in time and without a stop. The multiple resources of e-learning will not only motivate but also facilitate the learning of students, and thus improve the quality and efficiency of learning to all kinds of students. Moreover, the capacity and habit of self-directed learning will benefit the students for a lifetime.

Apart from above advantages, the weakness of elearning is seldom mentioned. For our opinions, elearning makes a higher request on both teachers and students. Based on self-directed learning, the communications between students and teachers are not that tight like classroom teaching. Students may feel lonely and disordered without the guidance of teacher. So the effectiveness of e-learning, to quite a large degree, hinges on the students' own initiative. If not highly capable of self-learning and selfregulation, many students may probably waste too much time surfing on the internet, instead of gaining systematical knowledge.

So, without the support and assistance of teachers, without effective measures to monitor and evaluate the results of the learners, the effectiveness of e-learning cannot be guaranteed. That is the reason why e-learning can never entirely replace classroom learning.

\section{BLENDED LEARNING}

Considering the drawbacks of e-learning and the relationships between e-learning and conventional classroom teaching, many scholars proposed an integrated model, named blended learning.

Alonso (2005) defined the blended learning as a combination of self-paced e-learning with face-toface instructor-led teaching. Carman (2005) figured out the five key ingredients of blended learning as "live event, self-paced learning, collaboration, assessment and reference material". According to these important elements of a blended learning process, it is obvious that this brand-new teaching model overcomes almost all the limitations of single classroom teaching or e-learning, and thus will improve the quality and efficiency of teaching. The advantages of blended learning can be summarized as follows:

1. Blended learning can extend the boundaries of lecture-based learning so that learning can occur at any time, any place, and students can have alternative ways to learn.

2. Blended learning can satisfy the needs and interests of individual students. Students can plan 
their studies and choose their own learning speed according to their different starting points.

3. By learning online, students can absorb a wide range of information and knowledge. The rich, colorful and interesting information online can significantly motivate the interests of learning.

4. Blended learning provides a favorable and harmonious learning environment to students. Prompt feedbacks from teachers can maintain students motivation. On the other hand, by checking students feedbacks, teachers can have a general idea of the students learning situation and introduce more related information to increase the depth of teaching.

5. Blended learning is a combination of the required learning and self-learning. After finishing the required work, students can learn whatever they are interested in. This demands the students to set clear learning objectives and plans, which will help to make good habits in autonomous learning.

\section{APPLICATION OF BLENDED LEARNING IN BIOCHEMISTRY TEACHING}

\subsection{Construction of e-learning platform for biochemistry course}

In order to apply blended learning model in biochemistry course, an e-learning platform, based on Blackboard learning management system (LMS), was constructed on the campus networks of Dalian Maritime University.

Blackboard is one of the leading commercial LMS products, provided by Blackboard Inc. It is widely adopted by universities all over the world due to its powerful and easy-to-use systems for educational instruction, communication and assessment.

Using Blackboard LMS, four modules were set up as the supplements to face-to-face teaching. The first module is online learning, including syllabus, electronic teaching plan, multimedia courseware, review questions, flash and videos. Students may flexibly use this part of resource to either preview or review the knowledge. The second module is online assessment, including question bank, mock examinations, standard answers and scoring system. Students may use this part of resource to practice and make a self-assessment on what they have learned. The third module is communication, including BBS for biochemistry, feedback mailbox, online questions \& answers, updating of the latest progress in biochemistry. This is the most active parts of the whole system. The forth module is teaching management, including personnel management, notice, homework setting, grades on assignments, score management. It helps manage every process of teaching activities.

\subsection{Assessment of blended learning effectiveness}

Thirty students of marine biology resources and environments major in Dalian Maritime University, China, took parts in this blended learning program. At the end of the semester, the average score, excellent rate and pass rate of these students were calculated and compared with those of the previous three academic years (Table 1).

Table 1. Statistics of scores in the final examination of biochemistry during four academic years

\begin{tabular}{|c|c|c|c|}
\hline $\begin{array}{c}\text { Academic } \\
\text { year }\end{array}$ & $\begin{array}{c}\text { Average } \\
\text { score }\end{array}$ & $\begin{array}{c}\text { Excellent } \\
\text { rate }(\%)\end{array}$ & $\begin{array}{c}\text { Pass rate } \\
(\%)\end{array}$ \\
\hline $2013-2014 *$ & 85.7 & 45.5 & 100.0 \\
\hline $2012-2013$ & 83.2 & 18.5 & 96.3 \\
\hline $2011-2012$ & 84.1 & 21.4 & 100.0 \\
\hline $2010-2011$ & 82.8 & 17.9 & 92.9 \\
\hline
\end{tabular}

*Blended learning model was applied in biochemistry teaching.

The statistic data demonstrated that applying blended learning model in biochemistry teaching achieved a better teaching efficiency than the single lecture-based teaching. The average score increased from 83.4 (three year average) to 85.7. The excellent rate significantly increased from $19.3 \%$ (three year average) to $45.5 \%$.

Additionally, the students were administered a questionnaire to assess the various aspects of their usage in this blended learning. Students evaluated the overall quality of the learning model (Table 2). The majority of students $(73.4 \%)$ gave a high rating to the learning effectiveness of the blended learning provided. Data exhibited that students found the blended learning could increase their interest and motivation of learning, improve the self-study ability and analytical capability. Almost all the students felt the blended learning was helpful for understanding and memorizing the knowledge they have learnt. In addition, the majority of students considered this teaching model promoting the interactions between teachers and students.

Table 2. Students' evaluation on the blended learning

\begin{tabular}{|l|c|c|c|}
\hline & $\begin{array}{c}\text { Remarkable } \\
(\%)\end{array}$ & $\begin{array}{c}\text { Common } \\
(\%)\end{array}$ & $\begin{array}{c}\text { No effect } \\
(\%)\end{array}$ \\
\hline $\begin{array}{l}\text { Learning } \\
\text { effectiveness }\end{array}$ & 73.4 & 23.3 & 3.3 \\
\hline Interest in learning & 80.0 & 13.3 & 6.7 \\
\hline $\begin{array}{l}\text { Motivation of } \\
\text { learning }\end{array}$ & 76.6 & 16.7 & 6.7 \\
\hline Self-study ability & 66.6 & 30.0 & 3.3 \\
\hline $\begin{array}{l}\text { Analytical } \\
\text { capability }\end{array}$ & 60.0 & 23.3 & 16.7 \\
\hline $\begin{array}{l}\text { Understanding \& } \\
\text { memory }\end{array}$ & 83.3 & 16.7 & 0 \\
\hline $\begin{array}{l}\text { Teacher-student } \\
\text { interactions }\end{array}$ & 70.0 & 23.3 & 6.7 \\
\hline
\end{tabular}


To sum up, the majority of students perceived that blended learning had made a positive impact on various aspects of their learning in biochemistry. The final scores they have gained fully demonstrated the effectiveness of this creative teaching model.

\section{CONCLUSION}

A blended learning model, combined e-learning with conventional lecture-based learning, was applied in biochemistry teaching for undergraduate students of marine biology resources and environments major, in Dalian maritime university, China. The attitude of the majority of students towards this blend learning in biochemistry course was very positive. The statistic data of teaching effectiveness demonstrated that applying this blended learning model in biochemistry achieved a better teaching efficiency than the single lecture-based teaching.

\section{ACKNOWLEDGEMENT}

This work was financially supported by "Teaching reform project" from the Education Department of Liaoning Province (UPRPI2014066), China.

\section{REFERENCES}

[1] Alonso, F. et al. 2005. An instructional model for webbased e-learning education with a blended learning process approach. British Journal of Educational Technology. 36 (2): 232-235.

[2] Luskin, B. 2010. Think "Exciting": E-Learning and the Big "E" (available at: http://www.educause.edu/ero/article/think-exciting-elearning-and-big-e)

[3] Nichols, M. 2003. A theory of E-learning. Educational Technology and Society 6 (2): 1-10.

[4] Parks, E. 2011. What's the "e" in e-Learning? (available at:

http://www.askinternational.com/knowledge/articles/eBasi c/whatsElearn.html) 